PNL-2878

UC-64

\title{
Statistical Nature of Cold Fronts Within the Gulf of Mexico and Their Potential Influence on OTEC Operations
}

S. L. Ulanski

December 1978

Prepared for the U.S. Department of Energy under Contract EY-76-C-06-1830

Pacific Northwest Laboratory Operated for the U.S. Department of Energy by Battelle Memorial Institute 


\title{
NOTICE
}

This report was prepared as an account of work sponsored by the United States Government. Neither the United States nor the Department of Energy, nor any of their employees, nor any of their contractors, subcontractors, or their employees, makes any warranty, express or implied, or assumes any legal liability or responsibility for the accuracy, completeness or usefulness of any information, apparatus, product or process disclosed, or represents that its use would not infringe privately owned rights.

The views, opinions and conclusions contained in this report are those of the contractor and do not necessarily represent those of the United States Government or the United States Department of Energy.

\author{
PACIFIC NORTHWEST LABORATORY \\ operated by \\ BATTELLE \\ for the \\ UNITED STATES DEPARTMENT OF ENERGY \\ Under Contract EY-76-C-06-1830
}
Printed in the United States of America

$$
\text { Available from }
$$
National Technical Information Service
United States Department of Commerce
5285 Port Royal Road
Springfield, Virginia 22151

Price: Printed Copy \$

-; Microfiche $\$ 3.00$

NTIS

\begin{tabular}{cc} 
•Pages & $\begin{array}{c}\text { NTIS } \\
\text { Selling Price }\end{array}$ \\
\hline $001-025$ & $\$ 4.00$ \\
$026-050$ & $\$ 4.50$ \\
$051-075$ & $\$ 5.25$ \\
$076-100$ & $\$ 6.00$ \\
$101-125$ & $\$ 6.50$ \\
$126-150$ & $\$ 7.25$ \\
$151-175$ & $\$ 8.00$ \\
$176-200$ & $\$ 9.00$ \\
$201-225$ & $\$ 9.25$ \\
$226-250$ & $\$ 9.50$ \\
$251-275$ & $\$ 10.75$ \\
\hline $276-300$ & $\$ 11.00$
\end{tabular}

276-300 $\quad \$ 11.00$ 
PNL -2878

UC -64

\section{5}

STATISTICAL NATURE OF COLD FRONTS WITHIN THE GULF OF MEXICO AND THEIR POTENTIAL INFLUENCE ON OTEC OPERATIONS

S. L. UTanski

December 1978

Prepared for

the U.S. Department of Energy

under Contract EY-76-C-06-1830

Pacific Northwest Labcratory

Richland, washington 99352 


\section{CONTENTS}

Page

TABLES . . . . . . . . . . . . . . . . . . . . . .

FIGURES. . . . . . . . . . . . . . . . . . . . . . . iv

INTRODUCTION . . . . . . . . . . . . . . . . . . . . . . . . . . 1

PROCEDURE. . . . . . . . . . . . . . . . . . . . . . . . 1

RESULTS. . . . . . . . . . . . . . . . . . . . . . 2

CONCLUSIONS. . . . . . . . . . . . . . . . . . . . . . . 14

REFERENCES . . . . . . . . . . . . . . . . . . . . . . 19 
$\underline{\text { TABLES }}$

Table

1 Number of Cold Fronts for Tampa, Florida

Page

2 The Average Interval in Days Between the Passage of Cold Fronts at Tampa, Florida

4

3 December Frontal Temperature Drop at 0100 LST for Tampa

4 January Frontal Temperature Drop at 0100 LST for Tampa

$5 \quad$ February Frontal Temperature Drop at 0100 LST for Tampa

6 Frequency and Probability of Frontal Temperature Change for Tampa

7 December Frontal Temperature Drop at 0100 LST for Key West

8 January Frontal Temperature Drop at 0100 LST for Key West

$9 \quad$ February Frontal Temperature Drop at 0100 LST for Key West

10 Frequency and Probability of Frontal Temperature Change for Key West 


\section{FIGURES}

Figure

Page

$1 \quad$ Winter Frontal Temperature Drop at Tampa, Florida from 1973 to 1976 .

2 Comparison of Frontal Temperature Changes for December versus January at Tampa, Florida.

3

Comparison of Frontal Temperature Changes

for January versus February at Tampa, Florida.

4

Return Period for Cold Front Changes Greater than $20^{\circ} \mathrm{F}$. 
STATISTICAL NATURE OF COLD FRONTS WITHIN THE GULF OF MEXICO

AND THEIR POTENTIAL INFLUENCE ON OTEC OPERATIONS

\section{$\underline{\text { INTRODUCTION }}$}

This study was undertaken to quantify selected aspects of cold fronts as they penetrate southward into the Gulf of Mexico region. A need arises to statistically define the nature of these cold fronts since the Department of Energy's Ocean Thermal Energy Conversion (OTEC) program is geared for determining the feasibility of utilizing the temperature difference between the tropical ocean surface and depths of approximately $1500 \mathrm{~m}$ for the production of power. However, severe winters are known to significantly decrease the normal sea surface temperature by approximately $7.2^{\circ} \mathrm{F}$ as well as cause deepening of the mixed layer (Leetmaa, 1977). With an OTEC plant operating at efficiencies of only 2 to 3 percent, the plant could become marginally operational during the winter months. This potential shutdown is in result of the sea temperature difference becoming less than that normally required for plant operation.

Upon the passage of a cold front, the sea surface will exchange heat to the atmosphere through the fluxes of latent and sensible heat. Garstang (1969) has shown that these fluxes can increase more than an order of magnitude upon the passage of a moderate cold front.

\section{PROCEDURE}

Long term, greater than 25 years, meteorological data from the National Climatic Center was used as the basis for determining the impact of cold fronts in the Gulf of Mexico region. In particular, surface air temperature and wind direction were analyzed daily during the months of December, January and February. The drop in temperature as well as the directional wind shift were the criteria for the frontal passage. Surface observation data from Tampa and Key West, Florida were used in the study. 


\section{RESULTS}

Throughout the period of record (1948-1976), the number of cold fronts passing Tampa, Florida (Table 1) on a yearly bas is range from 9 to 15 fronts, with the average being 12 fronts. January had the most fronts (127) throughout the record and February the least (93).

Though there is a gap in the data record for Key West (1953-1957), the total number of fronts reaching Key West is 250 compared to 293 which passed Tampa over the same period. In other words, 85 percent of the fronts which reach Central Florida penetrate as far southward as Key West. The fronts failing to reach Key West are dissipated due to warming and modification of the underlying sea and land.

Table 2 shows the average interval in days between the occurrence of fronts at Tampa. Though there exists a positive relationship between the number of fronts occurring during a particular year (Table 1) and the interval in days between the passage of consecutive fronts, more interesting is the characteristic (entire record) period, 6.4 days, between fronts. This value falls in between the theoretically determined periods of cyclone ( 1 wave per day) and Rossby (1 wave per 10 days) waves.

The maximum temperature change of the 0100 LST reading before and after the passage of a cold front was arbitrarily chosen as an indicator of cold front intensity (Tables 3,4 and 5). As to be expected, not only is there much variation in the temperature drop associated with the passage of consecutive fronts, but there also exists large yearly variations for particular months (Figure 1).

A closer examination of Figure 1 shows that the yearly peaks and troughs for the three months do not coincide. This observation then leads to the question if one month was characterized by particularly strong or weak cold fronts in a certain year did the following month exhibit similar characteristics? As evidenced by the scatter about the one to one fit (Figure 2), there exists only a weak relationship between the frontal temperature changes for December and January. Figure 3, for January and February, depicts a similar relationsinip to that of Figure 2 in that there 
TABLE 1. Number of Cold Fronts for Tampa, Florida

\begin{tabular}{ccccc} 
Yeär & December & January & February & Tota T \\
\cline { 1 - 1 } $1947-1948$ & - & 5 & 3 & $8^{\star}$ \\
$1948-1949$ & 4 & 4 & 2 & 10 \\
$1949-1950$ & 3 & 3 & 3 & 9 \\
$1950-1951$ & 4 & 3 & 2 & 9 \\
$1951-1952$ & 4 & 3 & 3 & 10 \\
$1952-1953$ & 5 & 3 & 4 & 12 \\
$1953-1954$ & 3 & 5 & 4 & 12 \\
$1954-1955$ & 5 & 6 & 2 & 13 \\
$1955-1956$ & 5 & 5 & 3 & 13 \\
$1956-1957$ & 4 & 4 & 3 & 11 \\
$1957-1958$ & 4 & 6 & 4 & 14 \\
$1958-1959$ & 4 & 6 & 2 & 12 \\
$1959-1960$ & 5 & 5 & 3 & 13 \\
$1960-1961$ & 3 & 5 & 3 & 11 \\
$1961-1962$ & 4 & 5 & 2 & 11 \\
$1962-1963$ & 5 & 4 & 6 & 15 \\
$1963-1964$ & 4 & 5 & 4 & 13 \\
$1964-1965$ & 3 & 4 & 3 & 10 \\
$1965-1966$ & 3 & 5 & 4 & 12 \\
$1966-1967$ & 4 & 4 & 4 & 12 \\
$1967-1968$ & 3 & 3 & 4 & 10 \\
$1968-1969$ & 4 & 4 & 5 & 13 \\
$1969-1970$ & 6 & 4 & 4 & 14 \\
$1970-1971$ & 3 & 5 & 4 & 12 \\
$1971-1972$ & 2 & 4 & 3 & 9 \\
$1972-1973$ & 3 & 5 & 3 & 11 \\
$1973-1974$ & 5 & 3 & 4 & 12 \\
$1974-1975$ & 5 & 5 & 2 & 12 \\
$1975-1976$ & 6 & 4 & 3 & 13 \\
$1976-$ & 6 & - & - & $6^{*}$
\end{tabular}

*partial record 
TABLE 2. The Average Interval in Days Between the Passage of Cold Fronts at Tampa, Florida

\begin{tabular}{|c|c|}
\hline Year & December-February \\
\hline $1947-1948$ & $7.0 *$ \\
\hline $1948-1949$ & 8.5 \\
\hline $1949-1950$ & 9.5 \\
\hline $1950-1951$ & 7.0 \\
\hline $1951-1952$ & 7.3 \\
\hline $1952-1953$ & 5.4 \\
\hline $1953-1954$ & 5.2 \\
\hline $1954-1955$ & 5.0 \\
\hline $1955-1956$ & 5.0 \\
\hline $1956-1957$ & 7.1 \\
\hline $1957-1958$ & 4.6 \\
\hline $1958-1959$ & 5.5 \\
\hline $1959-1960$ & 5.8 \\
\hline $1960-1961$ & 6.5 \\
\hline $1961-1962$ & 6.0 \\
\hline $1962-1963$ & 4.8 \\
\hline $1963-1964$ & 5.4 \\
\hline $1964-1965$ & -8.0 \\
\hline $1965-1966$ & 6.2 \\
\hline $1966-1967$ & 5.5 \\
\hline $1967-1968$ & 8.2 \\
\hline $1968-1969$ & 6.0 \\
\hline $1969-1970$ & 5.2 \\
\hline $1970-1971$ & 6.0 \\
\hline $1971-1972$ & 8.6 \\
\hline $1972-1973$ & 6.1 \\
\hline $1973-1974$ & 6.0 \\
\hline $1974-1975$ & 6.7 \\
\hline $1975-1976$ & 6.0 \\
\hline 1976- & $3.4^{\star}$ \\
\hline
\end{tabular}


TABLE 3. December Frontal Temperature Drop at 0100 LST for Tampa

\begin{tabular}{|c|c|c|}
\hline Year & $\Delta T\left({ }^{\circ} \mathrm{F}\right)$ & Avg. $\angle T\left({ }^{\circ} \mathrm{F}\right)$ \\
\hline \multicolumn{3}{|l|}{$1947-1948$} \\
\hline $1948-1949$ & $8,21,16,14,17$ & 15.2 \\
\hline $1949-1950$ & 11,14 & 12.5 \\
\hline $1950-1951$ & $17,23,22,18$ & 20.0 \\
\hline $1951-1952$ & $10,23,16,23$ & 18.0 \\
\hline $1952-1953$ & $21,15,13,19,20$ & 17.6 \\
\hline $1953-1954$ & $27,10,21$ & 19.3 \\
\hline $1954-1955$ & $9,25,15,29$ & 19.5 \\
\hline $1955-1956$ & $21,16,8,19$ & 16.0 \\
\hline $1956-1957$ & $21,3,28,19$ & 17.8 \\
\hline $1957-1958$ & $10,26,15,8$ & 14.8 \\
\hline $1958-1959$ & $23,21,3,12$ & 14.8 \\
\hline $1959-1960$ & $4,8,10,15,5$ & 8.4 \\
\hline $1960-1961$ & $30,16,15$ & 20.3 \\
\hline $1961-1962$ & $5,19,22,23$ & 17.3 \\
\hline $1962-1963$ & $10,18,24,3,18$ & 16.2 \\
\hline $1963-1964$ & $5,12,24,19$ & 15.0 \\
\hline $1964-1965$ & $28,18,2$ & 16.0 \\
\hline $1965-1966$ & $9,20,23$ & 17.3 \\
\hline $1966-1967$ & $28,15,28,20$ & 22.8 \\
\hline $1967-1968$ & $22,30,21$ & 24.3 \\
\hline $1968-1969$ & $21,20,29,29$ & 24.8 \\
\hline $1969-1970$ & $9,20,8,10,17,24$ & 13.0 \\
\hline $1970-1971$ & $5,19,29$ & 17.7 \\
\hline $1971-1972$ & 12,15 & 13.5 \\
\hline $1972-1973$ & $4,6,13$ & 14.3 \\
\hline $1973-1974$ & $32,11,27,22,7$ & 19.8 \\
\hline $1974-1975$ & $24,25,27,13,12$ & 20.2 \\
\hline $1976-1977$ & & \\
\hline
\end{tabular}


TABLE 4. January Frontal Temperature Drop at 0100 LST for Tampa

\begin{tabular}{|c|c|c|}
\hline Year & $\Delta T\left({ }^{\circ} \mathrm{F}\right)$ & Avg. $\Delta T\left({ }^{\circ} \mathrm{F}\right)$ \\
\hline $1947-1948$ & $19,22,16,22,25$ & 20.8 \\
\hline $1948-1949$ & $25,4,2,7$ & 9.5 \\
\hline $1949-1950$ & $12,5,5$ & 7.1 \\
\hline $1950-1951$ & $25,21,6$ & 17.3 \\
\hline $1951-1952$ & $23,19,24$ & 22 \\
\hline $1952-1953$ & $23,16,16$ & 18.3 \\
\hline $1953-1954$ & $8,23,11,16,10$ & 13.6 \\
\hline $1954-1955$ & $2,9,17,19,19,15$ & 13.5 \\
\hline $1955-1956$ & $7,18,12,12,14$ & 12.6 \\
\hline $1956-1957$ & $12,14,28,2$ & 14 \\
\hline $1957-1958$ & $19,27,17,8,5,9$ & 14.2 \\
\hline $1958-1959$ & $31,23,22,18,6$ & 21.2 \\
\hline $1959-1960$ & $17,2,18,24,14$ & 15 \\
\hline $1960-1961$ & $25,12,11,15,11$ & 14.8 \\
\hline $1961-1962$ & $20,21,11,22$ & 18.5 \\
\hline $1962-1963$ & $10,14,25,15$ & 16 \\
\hline $1963-1964$ & $20,19,35,17,14$ & 21.0 \\
\hline $1964-1965$ & $10,22,30,29$ & 25.5 \\
\hline $1965-1966$ & $24,20,21,29,19$ & 22.6 \\
\hline $1966-1967$ & $31,20,17,29$ & 24.3 \\
\hline $1967-1968$ & $12,22,24$ & 19.3 \\
\hline $1968-1969$ & $25,20,14,18$ & 19.3 \\
\hline $1969-1970$ & $28,11,23,22$ & 21 \\
\hline $1970-1971$ & $9,4,22,22,28$ & 17 \\
\hline $1971-1972$ & $24,29,15,11$ & 19.8 \\
\hline $1972-1973$ & $4,18,7,8,22$ & 11.8 \\
\hline $1973-1974$ & $7,4,3$ & 4.7 \\
\hline $1974-1975$ & $10,11,34,19,17$ & 18.2 \\
\hline $1975-1976$ & $16,30,30,30$ & 26.5 \\
\hline
\end{tabular}


TABLE 5. February Frontal Temperature Drop at 0100 LST for Tampa

\begin{tabular}{|c|c|c|}
\hline Year & $\Delta T\left({ }^{\circ} \mathrm{F}\right)$ & Avg. $\Delta T\left({ }^{\circ} \mathrm{F}\right)$ \\
\hline $1947-1948$ & $17,19,3$ & 13 \\
\hline $1948-1949$ & 15 & 15 \\
\hline $1949-1950$ & $6,23,12$ & 13.7 \\
\hline $1950-1951$ & 27,18 & 22.5 \\
\hline $1951-1952$ & $20,16,19$ & 18.3 \\
\hline $1952-1953$ & $12,14,15$ & 13.7 \\
\hline $1953-1954$ & $18,12,12,16$ & 14.5 \\
\hline $1954-1955$ & 13,31 & 22 \\
\hline $1955-1956$ & $12,19,19$ & 16.7 \\
\hline $1956-1957$ & $20,10,12$ & 14 \\
\hline $1957-1958^{\circ}$ & $27,19,19,12$ & 19.3 \\
\hline $1958-1959$ & 8,20 & 15 \\
\hline $1959-1960$ & $11,26,9$ & 15.3 \\
\hline $1960-1961$ & $10,15,19$ & 14.7 \\
\hline $1961-1962$ & 13,18 & 15.5 \\
\hline $1962-1963$ & $17,10,19,14,5,10$ & 12.5 \\
\hline $1963-1964$ & $13,13,16,23$ & 16.3 \\
\hline $1964-1965$ & $20,21,12$ & 17.7 \\
\hline $1965-1966$ & $13,7,20$ & 13.3 \\
\hline $1966-1967$ & $14,20,34$ & 22.7 \\
\hline $1967-1968$ & $18,15,10,17$ & 15 \\
\hline $1968-1969$ & $34,22,8,20$ & 21 \\
\hline $1969-1970$ & $37,16,13$ & 22 \\
\hline $1970-1971$ & $12,30,26,13$ & 20.3 \\
\hline $1971-1972$ & $25,16,17$ & 19.3 \\
\hline $1972-1973$ & $29,27,23$ & 26.3 \\
\hline $1973-1974$ & $25,27,13,20$ & 21.3 \\
\hline $1974-1975$ & 21 & 21.0 \\
\hline $1975-1976$ & $11,21,25$ & 19.0 \\
\hline
\end{tabular}




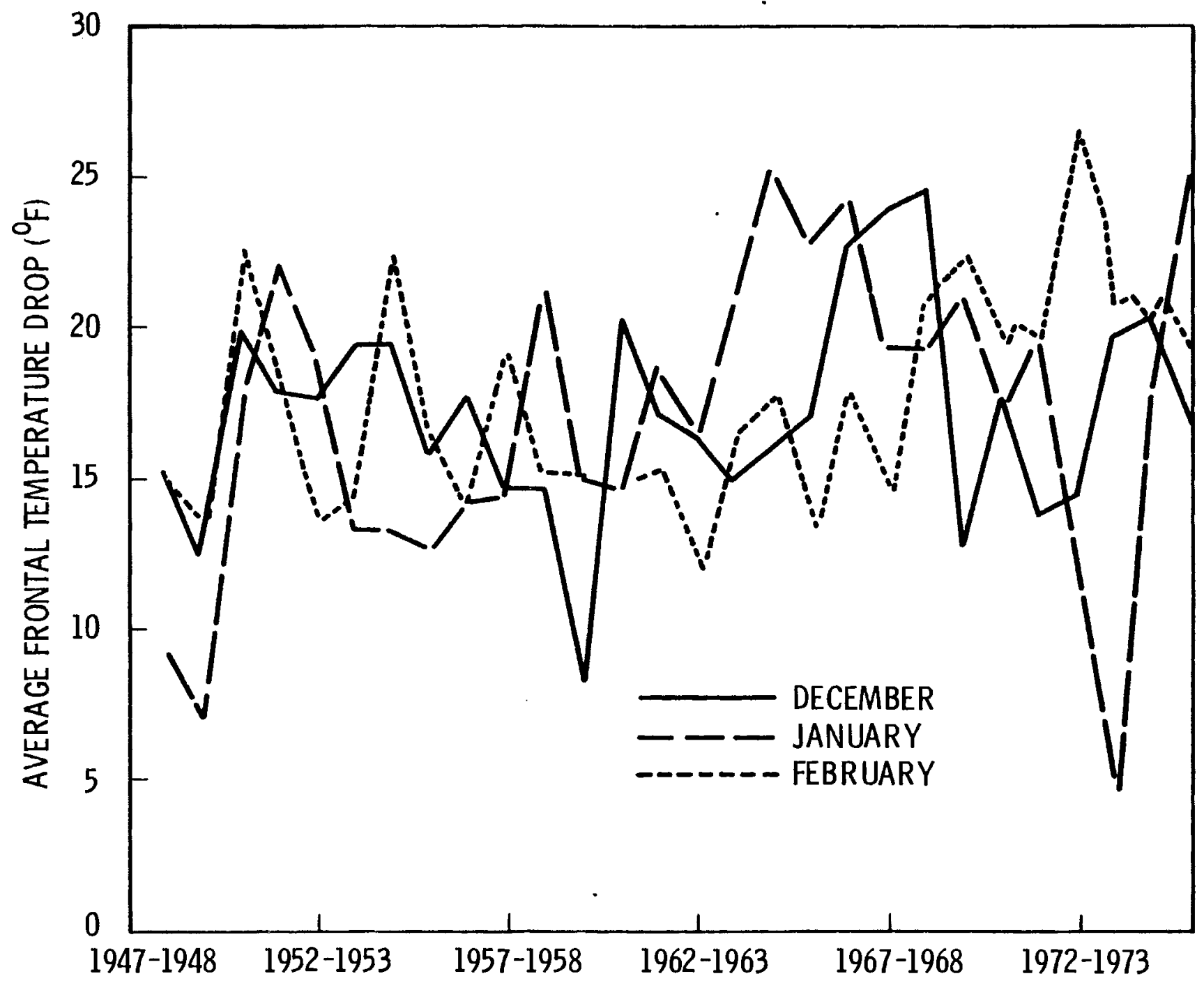

FIGURE 1. Winter Frontal Temperature Drop at Tampa, Florida from 1973 to 1976. 


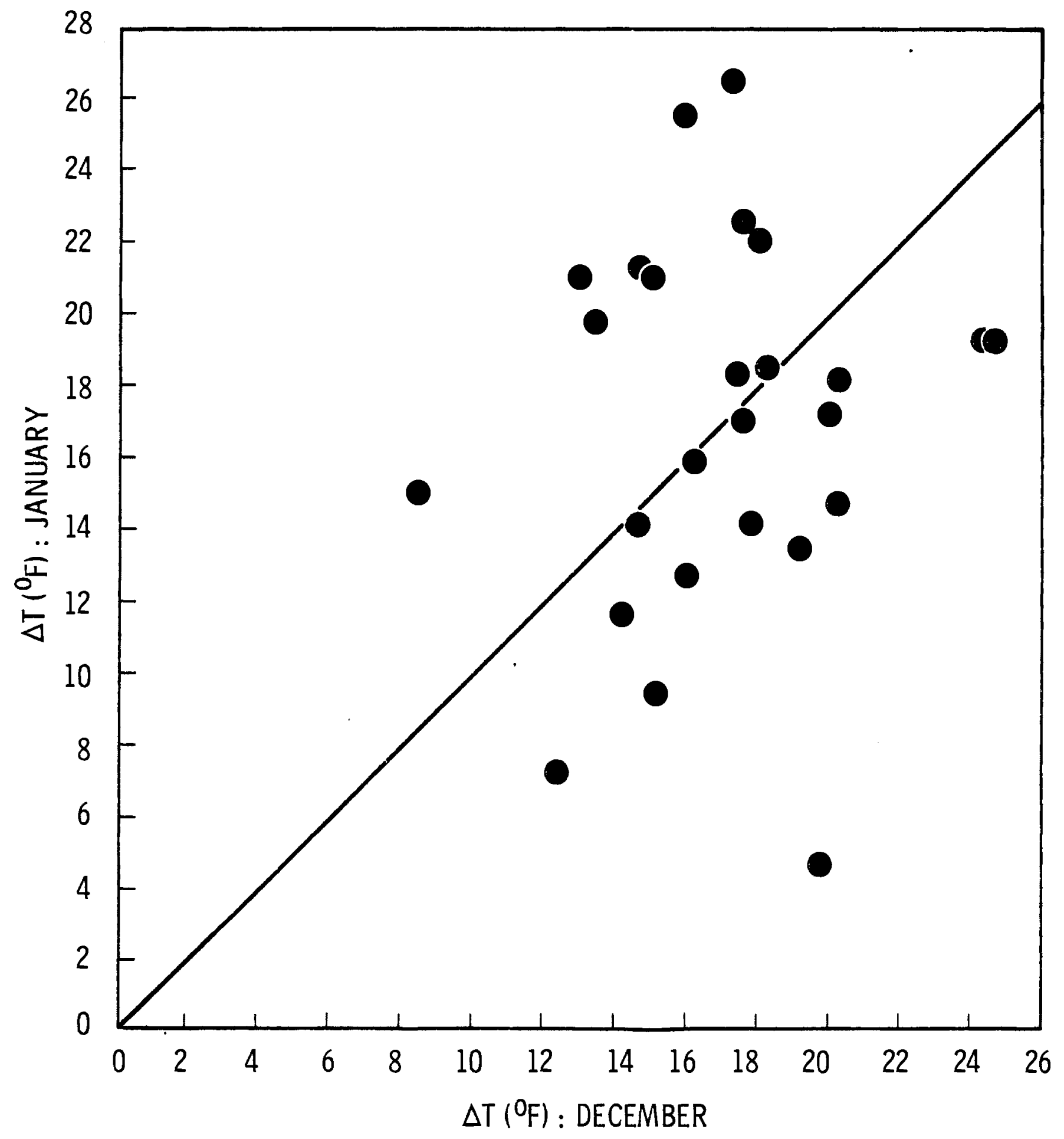

FIGURE 2. Comparison of Frontal Temperature Changes for December versus January at Tampa, Florida. 


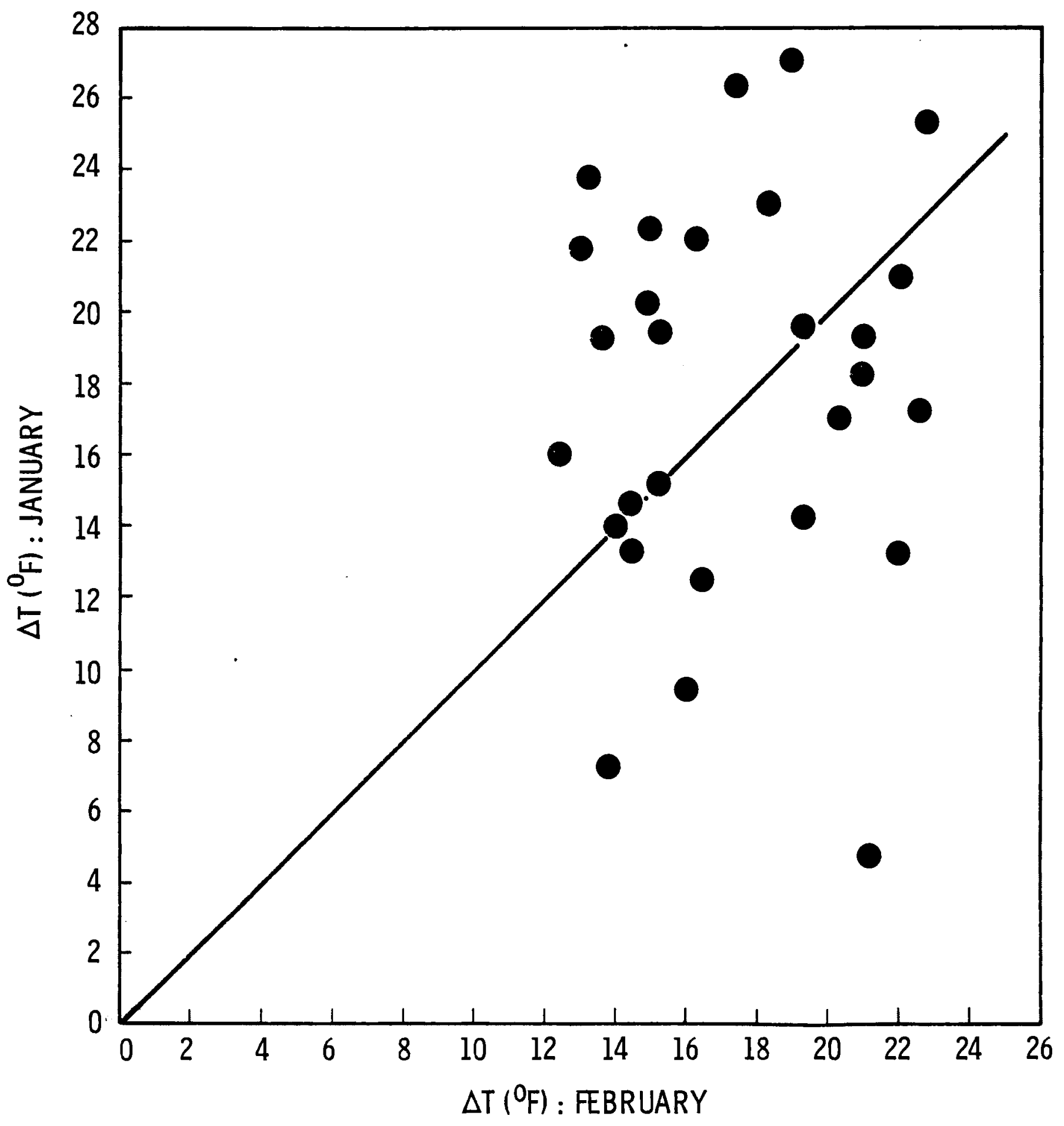

FIGURE 3. Comparison of Frontal Temperature Changes for January versus February at Tampa, Florida. 
is no evidence of strong monthiy persistence with regard to the intensity of the cold fronts.

With regard to the average frontal temperature change over the entire period of record, there was very 1 ittle difference from month to month. In particular, the average for December as $17.3^{\circ} \mathrm{F}$ compared to $17.1^{\circ} \mathrm{F}$ and $17.8^{\circ} \mathrm{F}$ for January and February respectively.

For Tampa, the temperature change intervals $11-15^{\circ} \mathrm{F}, 16-20^{\circ} \mathrm{F}$ and 21-25 ${ }^{\circ} \mathrm{F}$ exhibit the highest frequency and probability of occurrence (Table 6). Almost 70 percent of the fronts fal1 within this 15 degree interval. However, of potential interest to planners of the OTEC project is the time period for which on the average a particular event, in this case strong frontal temperature drops, will be equaled or exceeded. Figure 4 shows the return period in years for temperature changes greater than $20^{\circ} \mathrm{F}$. The return period increases logarithmically for increasing temperature changes. That is, very large drops in temperature may occur only once or twice within the proposed lifetime of the project. For example, the temperature interval $35-40^{\circ} \mathrm{F}$ has a return period of 28 years. Metz (1977) has pointed out that OTEC proponents are counting on the plants to operate satisfactorily with virtually no shutdown for 20 to 40 years. With this proposed design horizon as a benchmark, the chance that a severe temperature depression due to a cold front passage will be equaled or exceeded in the project's lifetime is calculated. That is

$$
P=1-(1-(1 / T))^{n}
$$

where

$$
\begin{aligned}
& P=\text { probability of event occurring } \\
& T=\text { return period of event } \\
& n=1 \text { ifetime of project }
\end{aligned}
$$


TABLE 6. Frequency and Probability of Frontal Temperature Change for Tampa

\begin{tabular}{|c|c|c|c|c|c|c|c|c|}
\hline & & & & ${ }^{\circ} \mathrm{F}$ ) & & & & \\
\hline & $0-5$ & $6-10$ & $11-15$ & $16-20$ & $21-25$ & $26-30$ & $31-35$ & $\therefore 35$ \\
\hline$f$ & 21 & 35 & 64 & 79 & 61 & 31 & 7 & 1 \\
\hline $\mathrm{P}(\%)$ & 7.0 & 11.7 & 21.4. & 26.4 & 20.4 & 10.4 & 2.3 & .3 \\
\hline
\end{tabular}




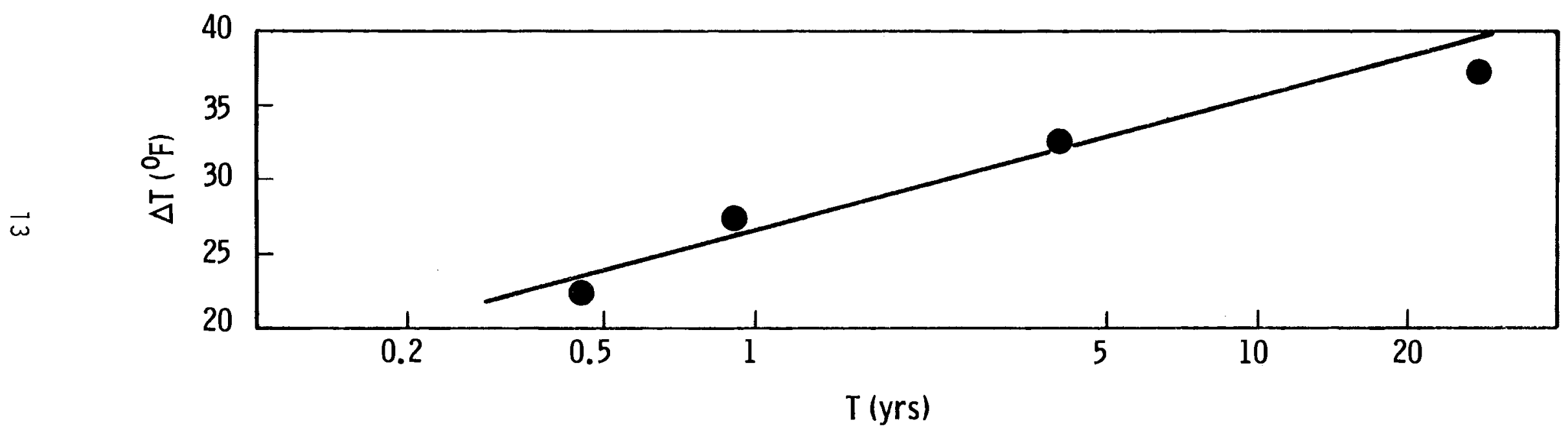

FIGURE 4. Return Period for Cold Front Changes Greater than $20^{\circ} \mathrm{F}$. 
Let $T=28$ years and $n=20$ years

$$
\begin{aligned}
& P=1-(1-(1 / 28))^{20} \\
& P=0.52
\end{aligned}
$$

That is there is a 52 percent chance that the severe temperature $\left(35^{\circ}\right.$ $40^{\circ}$ ) drop with the 28 year return period will be equaled or exceeded sometime during the lower 1 imit for the proposed existence of the OTEC plant. For 40 years, the risk value is 77 percent.

T.ables 7,8 and 9 present the decrease in temperature (0100 LST reading) after the passage of a cold front at key West. The values are lower than for Tampa as would be expected because of modification of the southward moving front. The monthly average values for the period of record are $10.3^{\circ}, 11.2^{\circ}$ and $10.7^{\circ} \mathrm{F}$ for December, January and February respectively. For each of the months, these values are approximately $7^{\circ} \mathrm{F}$ less than for Tampa.

In Table 10, note that more than 60 percent of the fronts fall within the temperature bracket of $6^{\circ}-15^{\circ} \mathrm{F}$. Furthermore, while the data for Tampa showed that 13 percent of the fronts were characterized by temperature drops of greater than $25^{\circ} \mathrm{F}$, this large temperature change was not in evidence as far south as Key West.

\section{CONCLUSIONS}

An analysis of the long term winter air temperatures within the Gulf of Mexico area has provided statistical information with regard to the frequency, number, intensity and southward penetration of cold fronts.

Hopefully, this information may be of use to OTEC planners when assessing feasibility of operating a sea based power plant for the production of power.

Directly, cold fronts have the effect of changing the thermal budget of the sea surface and the mixed layer. Indirectly, the winter wind stress increases the vertical mixing changing the depth of the well-mixed top layer of water. 
TABLE 8. January Frontal Temperature Drop at 0100 LST for Key West

\begin{tabular}{|c|c|c|}
\hline Year & $\Delta T\left({ }^{\circ} \mathrm{F}\right)$ & Avg. $\Delta T\left({ }^{\circ} \mathrm{F}\right)$ \\
\hline $1947-1948$ & $14,22,12,8$ & 14 \\
\hline $1948-1949$ & $8,3,3$ & 4.7 \\
\hline $1949-1950$ & 4,2 & 3 \\
\hline $1950-1951$ & 14,17 & 15.5 \\
\hline $1951-1952$ & 8,16 & 12 \\
\hline $1952-1953$ & $14,14,4$ & 10.7 \\
\hline $1953-1954$ & Missing & \\
\hline $1954-1955$ & Missing & \\
\hline $1955-1956$ & Missing & \\
\hline $1956-1957$ & Missing & \\
\hline $1957-1958$ & Missing & \\
\hline $1958-1959$ & Missing & \\
\hline $1959-1960$ & Missing & \\
\hline $1960-1961$ & $13,10,17,7$ & 11.8 \\
\hline $1961-1962$ & $16,14,13$ & 14.3 \\
\hline $1962-1963$ & $12,6,7,3$ & 7 \\
\hline $1963-1964$ & $9,22,11,3$ & 11.3 \\
\hline $1964-1965$ & $4,12,11$ & 9 \\
\hline $1965-1966$ & $11,12,15,20,19$ & 15.4 \\
\hline $1966-1967$ & $18,6,13$ & 12.3 \\
\hline $1967-1968$ & $4,6,14$ & 8 \\
\hline $1968-1969$ & $7,8,8,7$ & 7.5 \\
\hline $1969-1970$ & $7,24,5,9,11$ & 11.2 \\
\hline $1970-1971$ & $13,23,9$ & 15 \\
\hline $1971-1972$ & 6,14 & 10 \\
\hline $1972-1973$ & 7,16 & 11.5 \\
\hline $1973-1974$ & No fronts & No fronts \\
\hline $1974-1975$ & 16,3 & 9.5 \\
\hline $1975-1976$ & $18,21,17$ & 18.7 \\
\hline
\end{tabular}


TABLE 7. December Frontal Temperature Drop at 0100 LST for Key West

\begin{tabular}{|c|c|c|}
\hline Year & $\Delta T\left({ }^{\circ} \mathrm{F}\right)$ & Avg. $\Delta T\left({ }^{\circ} \mathrm{F}\right)$ \\
\hline \multicolumn{3}{|l|}{$1947-1948$} \\
\hline $1948-1949$ & $2,9,16$ & 9 \\
\hline $1949-1950$ & 4,2 & 3 \\
\hline $1950-1951$ & $10,16,10,13$ & 12.3 \\
\hline $1951-1952$ & $8,8,8$ & 8 \\
\hline $1952-1953$ & $13,12,6,6,19$ & 11.2 \\
\hline $1953-1954$ & Missing & \\
\hline $1954-1955$ & Missing & \\
\hline $1955-1956$ & Missing & \\
\hline $1956-1957$ & Missing & \\
\hline $1957-1958$ & Missing & \\
\hline $1958-1959$ & Missing & \\
\hline $1959-1960$ & Missing & \\
\hline $1960-1961$ & $17,10,13$ & 13.3 \\
\hline $1961-1962$ & $8,14,12$ & 11.3 \\
\hline $1962-1963$ & $8,16,13$ & 12.3 \\
\hline $1963-1964$ & $8,4,15,14$ & 10.3 \\
\hline $1964-1965$ & 8,8 & 8 \\
\hline $1965-1966$ & $6,11,9$ & 8.7 \\
\hline $1966-1967$ & $14,8,9,4$ & 8.8 \\
\hline $1967-1968$ & $7,20,8$ & 11.7 \\
\hline $1968-1969$ & $12,19,15$ & 15.3 \\
\hline $1969-1970$ & $4,20,9,11$ & 11 \\
\hline $1970-1971$ & $2,1,12$ & 5 \\
\hline $1971-1972$ & 6,5 & 5.5 \\
\hline $1972-1973$ & 18,12 & 15 \\
\hline $1973-1974$ & $12,15,15,20$ & 15.5 \\
\hline $1974-1975$ & $5,11,13,5$ & 8.5 \\
\hline $1975-1976$ & $2,6,7,10,7,8$ & 6.7 \\
\hline $1976-$ & $8,9,15,14,7$ & 10.6 \\
\hline
\end{tabular}


TABLE 9. February Frontal Temperature Drop at 0100 LST for Key West

\begin{tabular}{|c|c|c|}
\hline Year & $\Delta T\left({ }^{\circ} \mathrm{F}\right)$ & Avg. $\Delta T\left({ }^{\circ} \mathrm{F}\right)$ \\
\hline $1947-1948$ & 1,5 & 3 \\
\hline $1948-1949$ & 3 & 3 \\
\hline $1949-1950$ & $4,15,4$ & 7.7 \\
\hline $1950-1951$ & 21,10 & 15.5 \\
\hline $1951-1952$ & $17,12,4$ & 11 \\
\hline $1952-1953$ & $7,8,7,13$ & 8.8 \\
\hline $1953-1954$ & Missing & \\
\hline $1954-1955$ & Missing & \\
\hline $1955-1956$ & Missing & \\
\hline $1956-1957$ & Missing & \\
\hline $1957-1958$ & Missing & \\
\hline $1958-1959$ & Missing & \\
\hline $1959-1960$ & Missing & \\
\hline $1960-1961$ & $5,11,12$ & 9.3 \\
\hline $1961-1962$ & 4,11 & 7.5 \\
\hline $1962-1963$ & $10,14,12,4$ & 10.0 \\
\hline $1963-1964$ & $5,18,16$ & 13 \\
\hline $1964-1965$ & 7,18 & 12.5 \\
\hline $1965-1966$ & $16,10,3$ & 9.7 \\
\hline $1966-1967$ & 9,10 & 9.5 \\
\hline $1967-1968$ & 10,12 & 11 \\
\hline $1968-1969$ & $11,10,5,14,7$ & 9.4 \\
\hline $1969-1970$ & $22,7,9,12$ & 12.5 \\
\hline $1970-1971$ & $2,24,15,5$ & 11.5 \\
\hline $1971-1972$ & $17,6,17$ & 13.3 \\
\hline $1972-1973$ & $11,17,13$ & 13.7 \\
\hline $1973-1974$ & $10,16,8,24$ & 14.5 \\
\hline $1974-1975$ & 11,8 & 9.5 \\
\hline $1975-1976$ & $11,10,11$ & 10.7 \\
\hline
\end{tabular}


TABLE 10. Frequency and Probability of Frontal Temperature Change for Key West

\begin{tabular}{|c|c|c|c|c|c|}
\hline & \multicolumn{4}{|c|}{$\Delta T\left({ }^{\circ} \mathrm{F}\right)$} & \multirow[b]{2}{*}{$21-25$} \\
\hline & $0-5$ & $6-10$ & $11-15$ & $16-20$ & \\
\hline$f$ & 31 & 66 & 56 & 32 & 7 \\
\hline$P(\%)$ & 16.1 & 34.4 & 29.2 & 16.7 & 3.6 \\
\hline
\end{tabular}




\section{REFERENCES}

Garstang, M., 1969: Development of experimental systems for, and the study of meso- and convective-scale systems and air-sea interaction in the maritine tropics. Final Report: Phase III to U. S. Dept. of Commerce, Florida State University.

Leitmaa, A., 1977: Effects of the winter of 1976-1977 on the Northwestern Sargasso Sea. Science, 198, pp. 188-189.

Metz, W. D., 1977: Ocean thermal energy: The biggest gamble in solar power. Science, 198, pp. 178-180. 
No. of

Copies

OFFSITE 